Available online on 15.09 .2015 at http://jddtonline.info
Journal of Drug Delivery and Therapeutics
Open access to Pharmaceutical and Medical research
(c) 2015, publisher and licensee JDDT, This is an Open Access article which permits unrestricted noncommercial use, provided the original
work is properly cited

\title{
CLOVE (SYZYGIUM AROMATICUM L.) AND THEIR EFFECT ON THE FORMATION OF HETEROCYCLIC AMINES
}

\author{
Abou-Baker Salim; El-Desouky T. A and Lamyaa EL-Sedeek \\ ${ }^{a}$ Food Toxicology and Contaminants Dept. National Research Centre., Dokki, Cairo, Egypt \\ *Corresponding authore-mail: eldesoukyt@yahoo.com \& tarekeldesouky6@gmail.com
}

Received 07 July 2015; Review Completed 28 July 2015; Accepted 11 August 2015, Available online 15 Sep 2015

\begin{abstract}
ABSRACT
Heterocyclic amines (HCAs) are a group of toxic chemicals, play an important role in the etiology of human cancer which formed at high temperature during cooking meat and fish. Antioxidants have proved to inhibit the formation of HCAs due to different mechanisms scavenging free radical, inhibits oxidative enzymes like cyochrome P450 and chelates metal ions like $\mathrm{Fe}^{+2}$ as well as protecting lipids against oxidation. Clove has potent antioxidants and antimicrobial activities standing out among the other species. Therefore current study done to show efficiency of $0.5 \%$ clove at preventing the formation of two most common HCAs: 2-amino-3,8-dimethylimidazo[4,5-f]quinoxaline (MeIQx) and 2-amino-1-methyl-6-phenylimidazo[4,5b]pyridine (PhIP) through seasoning of beef steaks before grilling and estimate antioxidant status of animals fed on the experimental diets. HCAs levels in food and blood samples were analyzed by HPLC. The results showed that content of MeIQx and PhIP in grilled beef meat steak were $23.0 \pm 2.87$ and $15.0 \pm 2.14 \mathrm{ng} / \mathrm{g}$, respectively. While the content of MeIQx and $\mathrm{PhIP}$ in seasoning grilled steak were degraded to $1.9 \pm 0.31$ and $1.6 \pm 0.23 \mathrm{ng} / \mathrm{g}$, respectively. On the other hand the results showed that the percentages of reduction of MeIQx and PhIP were 91.7 and $89.3 \%$ in seasoning grilled steak, respectively comparing with un- seasoning grilled steak. The levels of tested HCAs also showed significant differences among rat groups fed on the experimental diets. The highest MeIQx and PhIP concentrate in serum rats group fed on untreated grilled meat diet (positive control) were $11.1 \pm 1.85$ and $8.77 \pm 8.77 \mathrm{ng} / \mathrm{ml}$, respectively, while seasoning with $0.5 \%$ clove before grilling led to decrease in MeIQx and PhIP concentrate to $0.82 \pm 0.16$ and $0.51 \pm 0.09 \mathrm{ng} / \mathrm{ml}$ respectively with decreasing percent reached 92.6 $\%$ and $94.2 \%$ respectively. In addition, the results revealed that fed rats on un-seasoning grilled steak (positive control) caused high significant increased in lipid peroxide (malonaldhyde, MDA) accompanied by significant decreased in the levels of reduced glutathione content (GSH) and activities of antioxidant defense enzymes glutathione peroxidase (GHPx) and catalase (CAT), compared with basal diet group (negative control). However, clove treatment group lowered the level of lipid peroxidation and enhanced the antioxidant status of animals. Seasoning beef meat steaks before grilling with potent antioxidant clove species inhibit HCAs formation and their potential hazards to human health. This might be due to the powerful antioxidant activity of clove as strong hydrogen donating, metal chelating and scavenging of free radicals, hydrogen peroxide and superoxide.
\end{abstract}

Keywords: Heterocyclic amines (HCAs), 2-amino-3,8-dimethylimidazo[4,5-f]quinoxaline (MeIQx) , 2-amino-1-methyl-6phenylimidazo[4,5-b]pyridine (PhIP), clove, grilled beef meat, antioxidant plants, lipid peroxide, antioxidant defense enzymes.

\section{I.NTRODUCTION}

Heterocyclic aromatic amines (HCAs) are potent mutagens at nanogram per gram (ng/g) levels in cooked meat, poultry and fish at high temperature and play an important role in the etiology of human cancer (Sugimura, 2002). The mutagenicity of HCAs in meat has been assessed by using the microsom test of Ames/Salmonella and HCAs are found over 100 fold more mutagenic than aflatoxin $\mathrm{B}_{1}$ and over 2,000-fold more mutagenic than benzo[a]pyrene (Stavric, 1994; Knize, et al., 1995; Sugimura et al, 2004). The United States $12^{\text {th }}$ Report on Carcinogens reported that MeIQ, MeIQx, IQ, and PhIP were reasonably anticipated to be human carcinogens (NTP, 2011). The most common HCAs in cooked foods are 2-amino-3,8dimethylimidazo[4,5-f]quinoxaline (MeIQx) and 2amino-1-methyl-6-phenylimidazo[4,5-b]pyridine
(PhIP), which are classified as mutagens in the Ames test and exhibit carcinogenicity in animal testing (Nagao et al., 1977; Sugimura, et al., 2004). Zsivkovits et al., (2003) reported that MeIQx and PhIP induced DNA damage in colon and liver of rats. Tang et al., (2007) found a significant association between total meat consumption and total grilled red meat consumption with PhIP-DNA adducts. Furthermore, specific meats including, grilled hamburger, grilled steak, grilled pork chop, grilled hot dog, and grilled chicken with skin were associated with the occurrence of PhIP-DNA adducts in prostate tumor cells. Findings suggest that PhIP not only has the ability to propagate but also to promote cancer causing cells (Lauber and Gooderham 2011). Usually HCAs were occurring in 
foods at the $\mathrm{ng} / \mathrm{g}$ range, their risk is still relevant to consumers (Murkovic 2007; NTP, 2011).

Many HCAs formed via the Maillard reaction from creatine, creatinine, free amino acids and monosaccharide, compounds that occur naturally in protein-rich foods of animal origin. The development of the Maillard reaction occurs through a free radical mechanism that has been shown to play an important role in the formation of imidazoquinoxalines and imidazoquinolines (Jägerstad et al., 1998). The reactive intermediates such as pyrazinum and pyridinum cation radicals can be inactivated by the anti-oxidative effect of spices/herbs. In addition heat and mass transfer, lipid oxidation and antioxidants have effect on concentration of HCAs (Philippe et al., 2000; Kapan and Kaya, 2007; Alaejos and Afonoso, 2011). Prevention of freeradicals, as an intermediate in the Maillard reaction, would likely decrease the formation of HCAs (Murkovic et al., 1998; Kikugawa 1999).

Previous studies found that many factors play important roles in the formation of HCAs includes adding antioxidant spices or other materials to meats reduce formation of HCAs, so different strategies and methods have been developed to mitigate of HCAs in food successfully. The methods of adding antioxidant spices to meat include incorporation into meat, surface application, and marinating. Tsen et al., (2006) found that mixing antioxidant materials, such as spices rosemary powder into meat effectively reduces HCAs formation. Methods of adding inhibitory ingredients include surface application and marinating. Reduction of HCAs formation has been associated with surface application of antioxidant spices such as powders of rosemary, sage, thyme, and garlic, individually (Murkovic et al., 1998) and Vitamin E (Balogh et al., 2000). Also, commercially available marinades are capable of reducing HCAs (Smith et al., 2008). Marinades which include antioxidants such hibiscus, garlic, and onion were inhibited HCAs formation in fried beef patties (Gibis 2007; Gibis and Weiss 2010), green tea (Weisburger , et al., 2002; Quelhas et al., 2010). As well as Gibis and Weiss, (2012) reported that the content of MeIQx and PhIP were significantly reduced $57 \%$ and $90 \%$, respectively, after use of marinades containing the highest extract concentration of grape seed.

Antioxidants can act as inhibitors along the different pathways of reaction, preventing the mutagens formation through radical quenchers and free radical scavengers activity or preventing the biotransformation of pre-mutagens into reactive metabolites by inhibiting metabolic activation (Dashwood, 2002). Antioxidants also reduce the cellular damage resulting from interaction between lipid, protein and DNA molecules and reactive oxygen species (ROS). Regardless of the presence of this antioxidant system an over or unbalanced production of ROS due to contact with chemicals may resulted in a number of clinical disorder. ROS are scavenged by the endogenous antioxidant defense system, including superoxide dismutase (SOD), catalase (CAT), and reduced glutathione $(\mathrm{GSH})$ in cells (Bindhumol, et al., 2003).
Clove (Syzygium aromaticum L.) is one of the most valuable spices that have been as food preservative and for many medicinal purposes. Clove in particular has attracted the attention due to the potent antioxidant and antimicrobial activities standing out among the other spices (Shan et al., 2005). It represents one of the major vegetal sources of phenolic compounds as flavonoids, hidroxibenzoic acids, hidroxicinamic acids and hidroxiphenyl propens. Eugenol is the main bioactive compound of clove, which is found in concentrations ranging from $9,381.70$ to $14,650.00 \mathrm{mg}$ per $100 \mathrm{~g}$ of fresh plant material (Perez-Jimenez et al., 2010). With regard to the phenolic acids, gallic acid is the compound found in higher concentration $(783.50 \mathrm{mg} / 100 \mathrm{~g}$ fresh weight). However, other gallic acid derivates as hidrolizable tannins are present in higher concentrations (2 $375.8 \mathrm{mg} / 100 \mathrm{~g}$ ) (Shan et al., 2005). Other phenolic acids found in clove were the caffeic, ferulic, elagic and salicylic acids. Flavonoids as kaempferol, quercetin and its derivates (glycosilated) are also found in clove in lower concentrations. Concentrations up to $18 \%$ of essential oil can be found in the clove flower buds. Roughly, $89 \%$ of the clove essential oil is eugenol and $5 \%$ to $15 \%$ is eugenol acetate and $\beta$-cariofileno (Jirovetz et al., 2006). Another important compound found in the essential oil of clove in concentrations up to $2.1 \%$ is $\alpha$-humulen. Volatile compounds present in lower concentrations in clove essential oil are $\beta$-pinene, limonene, farnesol, benzaldehyde, 2-heptanone and ethyl hexanoate (Diego Francisco Cortés-Rojas et al 2014). Therefore, this study investigate the efficiency of clove (S. aromaticum) applied to the surface of beef meat steaks before grilling at preventing the formation of two most common HCAs: 2-amino-3,8dimethylimidazo[4,5-f]quinoxaline (MeIQx) and 2amino-1-methyl-6-phenylimidazo[4,5-b]pyridine (PhIP) and estimate antioxidant status of animals fed on the experimental diets.

\section{MATERIALS AND METHODS}

\section{II.I. Materials}

\section{Beef meats samples}

Beef meats were purchased from a local grocery store in Giza, Egypt. The grocery store cut it to steaks. The steaks were placed in individual freezer bags and frozen until use.

\section{Plant material}

Experimental plant clove (Syzygium aromaticum L.) species was purchased from a local market, Cairo, Egypt and then ground with blender $(2000 \mathrm{rpm})$ to obtain fine powder.

\section{MeIQx and PhIP}

MeIQx and PhIP standard was obtained from SigmaAldrich, St. Louis, USA.

\section{Experimental animals}

Twenty one adult male Sprague-Dawley albino rats average weight $(115 \pm 3 \mathrm{~g})$ were purchased from the Laboratory Animal Department, Research Institute of Ophthalmology, Giza, Egypt. The animals were housed 
in plastic cages under normal health laboratory condition at $25^{\circ} \mathrm{C} \pm 2{ }^{\circ} \mathrm{C}$ with timed lighting $12 \mathrm{~h}$ and relative air humidity of $40-60 \%$ and fed on basal diet for one week as an adaptation period. After the adaptation period ( 1 week), the rats were randomly divided into 3 groups ( 7 rats for each group).

\section{II.II. Methods}

\section{Preparation of beef meat grilled steak samples}

Beef meat steaks grilled on the open direct flame at more than $200^{\circ} \mathrm{C}$ for 5-7 min for each side. For direct application of spices treatment, steaks were seasoning well directly on to each side with $0.5 \%$ clove powder overnight in refrigerator before grilled. After cooking all samples were cooled at room temperature for an hour, the samples were minced in a grinder, packed in polyethylene pages and preserved in deep freezer at $18^{\circ} \mathrm{C}$ until tested.

\section{Determination of MeIQx and PhIP in grilled steak samples}

MeIQx and PhIP were determined by High performance liquid chromatography (HPLC) methods as described by (Zochling and Murkovic, 2002; Messner and Murkovic 2004)

High performance liquid chromatography (HPLC), HP Series II, 1090A (Palo Alto, CA, USA) fitted with a photodiode array ultraviolet (UV)-visible detector (HP 1040) and a fluorescent detector was used for separation and identification of HCAs. Detection of HCAs was achieved by both UV and fluorescence detectors. The UV detector was set at $263 \mathrm{~nm}$ wavelength for monitoring MeIQx. For PhIP, the maximum excitation was $229 \mathrm{~nm}$ and the emission was $437 \mathrm{~nm}$.

\section{Experimental design}

The basal diet was prepared according to the method described by A.O.A.C. (2005). The rats were randomly divided into three groups each of 7 animals and treated 8 weeks as follows: the first group (G1) received basal diet (negative control), the second group (G2): rats fed on un-seasoning grilled beef meat steak (positive control) and the third group (G3): rats fed on seasoning grilled beef meat steak with $0.5 \%$ clove powder.

\section{Biochemical analysis}

The blood samples were collected at the end of experimental period. The blood samples were collected from eye plexuses into both heparinized tubes and into a dry clean centrifuge glass tube without any coagulation to prepare serum. Blood samples were left for15 minutes at room temperature, then the tubes were centrifuged for $15 \mathrm{~min}$ at $3000 \mathrm{rpm}$ and the clean supernatant serum was kept frozen at $-20^{\circ} \mathrm{C}$ until the time of analysis. Antioxidant statuses of animals fed on the experimental diets were evaluated by estimated lipid peroxide (malonalddhyde, MDA) according to the method of (Satoh, 1979). Glutathione (GSH) activity and Glutathione peroxidase (GHPx) were determined according to method of Paglia and Valentine (1967) and catalase activity (CAT) was determined according to the method of (Fossati and Prencipe 1982 and Aebi, 1984).

\section{Determination of MeIQx and PhIP in blood of rats}

MeIQx and PhIP were determined in blood serum according to methods described by Robert et al., (1993) using HPLC.

\section{Statistical analysis}

Data were subjected to analysis of variance (ANOVA) and computing using the SAS General Linear Model producer (SAS, 1990). All statements of significance were based on probability of $\mathrm{P}<0.05$.

\section{RESULTS AND DISCUSION}

\section{III.I. Levels of HCAs in grilled beef meat steaks}

The results of comparing seasoning with $0.5 \%$ clove overnight and un-seasoning beef meat steaks before grilling are shown in Table 1. An average decrease greater than $90.5 \%$ in sum of HCAs observed. Grilled beef meat steak (un-seasoning) had $23.0 \pm 2.87 \mathrm{ng} / \mathrm{g}$ of MeIQx, and $15.4 \pm 2.14 \mathrm{ng} / \mathrm{g}$ of PhIP. These results agree with the results of Smith et al., (2008) who found that the dominant HCAs in beef meat steaks was MeIQx $(30 \pm 4.14 \mathrm{ng} / \mathrm{g})$ followed by PhIP $(14.4 \pm 4.73 \mathrm{ng} / \mathrm{g})$. These amounts significantly decreased $(\mathrm{P} \leq 0.05)$ to 1.9 $\pm 0.31 \mathrm{ng} / \mathrm{g}$ of MeIQx and $1.6 \pm 0.23 \mathrm{ng} / \mathrm{g}$ of $\mathrm{PhIP}$ respectively for seasoning beef meat steaks with $0.5 \%$ clove powder overnight before grilling with decreasing percent reached to $91.7 \%$ and $89.3 \%$ comparing with un-seasoning grilled meat. This result confirmed with other previously studies. Murkovic et al., (1998) showed that applied the ground powders of rosemary, sage, thyme, and garlic, individually, to the surface of beef 24 hours prior to pan-frying lead to significant reduction in HCAs. Vitamin $\mathrm{E}$ at $1 \%$ of the total meat weight was applied to the surface of ground beef patties 30 minutes prior to pan-frying resulted in a significant reduction in formation of all HCAs of interest (Balogh et al., 2000). Verdin (2002) also studied several spices as antioxidants and possible HCA reducers, the spices used were basil, garlic, ginger, onion, oregano, rosemary, sage, thyme. In addition, Tsen et al., (2006) demonstrated that addition of $0.3 \%$ rosemary powder mixed with ground beef 2 hours prior to grilling significantly reduced MeIQx by $57 \%$ and PhIP by 77.1 $\%$. On the other hand, Smith et al .,2008) indicated that Caribbean marinated contained amounts considerable

amounts of the polyphenolic antioxidants carnosic acid, carnosol, and rosmarinic acid decreased MeIQx from 30 $\pm 6.4 \mathrm{ng} / \mathrm{g}$ to $3.1 \pm 0.62 \mathrm{ng} / \mathrm{g}$ and from $17.4 \pm 4.73 \mathrm{ng} / \mathrm{g}$ to $2.33 \pm 0.15 \mathrm{ng} / \mathrm{g}$ of PhIP in grilled meat steak. Farag, (2014) found that seasoning beef meat with $1 \%$ ginger over time before grilling that led to decrease IQ concentrate from $14.368 \mathrm{ng} / \mathrm{g}$ (ppb) to $3.367 \mathrm{ng} / \mathrm{g}$ with decreasing percent reached to $76.56 \%$. 


\begin{tabular}{|l|c|c|}
\hline \multicolumn{2}{|c|}{${\text { Table1. Levels of } \text { HCAs }^{\mathbf{a}} \text { in grilled and pre-seasoning grilled beef meat steaks }}^{\mathbf{b}}$} \\
\hline Treatments & \multicolumn{2}{|c|}{ compounds(ng/g) mean $\pm \mathrm{SD}$} \\
\cline { 2 - 3 } & Me IQx & $\mathrm{Ph} \mathrm{IP}$ \\
\hline Grilled beef meat steaks & $23 \pm 2.87$ & $15 \pm 2.14$ \\
\hline pre-seasoning grilled beef meat steaks & $1.9 \pm 0.31$ & $1.6 \pm 0.23$ \\
\hline Inhibition\% & & 89.3 \\
\hline
\end{tabular}

${ }^{a}$ HCAs : 2-amino-3,8-dimethylimidazo[4,5-f]quinoxaline (MeIQx) and 2-amino-1-methyl-6-phenylimidazo[4,5b]pyridine (PhIP)

${ }^{b}$ : Seasoning grilled beef meat steaks with $0.5 \%$ clove powder overnight before grilling.

Each value represents the mean $\pm S D$ of 5 replicates.

Antioxidants have proved to inhibit the formation of HCAs due to both mechanisms scavenging the intermediary pyrazine cation radical as well as protecting lipids against oxidation. The use of antioxidants as free radical scavengers have demonstrated efficiency in stabilizing these intermediates, thereby reducing the HCA levels (Nagao et al., 2000; Verdin ,2002). Phenolic antioxidants such as rosemary and thyme were already shown to effectively inhibit the formation of IQ type HCAs because they contain free radical scavengers (Murkovic et al., 1998; Kikuguwa et al., 2004). Direct interactions and noncovalent heterocomplexes formation may be one of the most important mechanisms of antioxidant polyphenol protection against genotoxic effects of HCAs (Osowski et al., 2010). Among spices, clove showed the higher content of polyphenols and antioxidant compounds. The major types of phenolic compounds found were phenolic acids (gallic acid), flavonol glucosides, phenolic volatile oils (eugenol, acetyl eugenol) and tannins. Eugenol is the main bioactive compound of clove, which found in concentrations ranging from 9381.70 to 14650.00 $\mathrm{mg} / 100 \mathrm{~g}$ of fresh plant material (Shan et al., 2005; Perez-Jimenez et al., 2010). It was highlighted the huge potential of clove as radical scavenger and as a commercial source of polyphenols. The powerful antioxidant activity of clove extracts may be attributed to the strong hydrogen donating ability, metal chelating ability and scavanging of free radicals, hydrogen peroxide and superoxide (Gülçina et al., 2004). Eugenol allows the donation of an hydrogen atom and subsequent stabilization of the phenoxyl radical generated forming stable compounds that do not start or propagate oxidation. The eugenol molecule possesses an interesting conjugation of the carbon chain with the aromatic ring which could participate in the stabilization of the phenoxyl radical by resonance (Gülçin İ, 2011).

\section{III.II. Levels of HCAs in blood serum of rats fed on experimental diets}

HCAs concentrate (ppb) in blood serum of rats fed on experimental diets are shown in Table 2. The results revealed significant differences among rats groups. the highest MeIQx and PhIP concentrate for rats group fed on grilled meat (positive control) were $11.1 \pm 1.85 \mathrm{ng} / \mathrm{ml}$ (ppb), respectively. On the other hand seasoning beef meat steaks with $0.5 \%$ clove overnight before grilling that led to significant decrease $(\mathrm{P} \leq 0.05)$ in MeIQx and PhIP concentrate to and $0.82 \pm 0.16 \mathrm{ng} / \mathrm{ml}$ and $0.51 \pm 0.09 \mathrm{ng} / \mathrm{ml}$ in serum respectively with decreasing percent reached to $92.6 \%$ and $94.2 \%$,respectively. Farag (2014) found that $1 \%$ ginger over time before grilling that led to decrease IQ concentrate in food, serum and urine to $3.367 \mathrm{ng} / \mathrm{g}, 0.49 \mathrm{ng} / \mathrm{ml}$ and 1.74 $\mathrm{ng} / \mathrm{ml}$, respectively with decreasing percent reached to 76.56, 93.17 and $91.37 \%$, respectively comparing with un-seasoning grilled meat.

\begin{tabular}{|c|c|c|}
\hline \multicolumn{2}{|c|}{ Table 2: HCAs $^{\text {a }}$ Levels in blood serum of rats fed on experimental diets. } \\
\cline { 2 - 3 } & \multicolumn{2}{|c|}{ Compounds (ng/ml) mean \pm SD } \\
\cline { 2 - 3 } & Me IQx & Ph IP \\
\hline G1: basal diet (-ve control) & ND & \\
\hline G2: grilled beef meat steaks (+ve control) & $11.1 \pm 1.85$ & $8.77 \pm 1.75$ \\
\hline G3: pre-seasoning grilled beef meat steaks & $0.82 \pm 0.16$ & $0.51 \pm 0.08$ \\
\hline
\end{tabular}

${ }^{a}$ HCAs : 2-amino-3,8-dimethylimidazo[4,5-f]quinoxaline (MeIQx) and 2-amino-1-methyl-6-phenylimidazo[4,5b]pyridine (PhIP)

${ }^{\mathrm{b}}$ : Seasoning grilled beef meat steaks with $0.5 \%$ clove powder overnight before grilling.

${ }^{c}$ : Each value represents the mean \pm SD of 5 replicates. 


\section{III.III. Effect of experimental diets on oxidation state and antioxidant enzymes of rats}

The results in Fig (1) demonstrated significant increased $(\mathrm{P} \leq 0.05)$ in lipid peroxidase (malondialdehyde, MDA) and decrease in glutathione content (GSH) in rats fed on grilled meat (positive control) compared with rats fed on basal diet (negative control). The increased MDA level and decreased GSH concentration indicate an increased generation of ROS, which cause lipid peroxidation in the liver (Nandi et al., 2005). ROS is capable of damaging crucial biomolecules such as nucleic acids, lipids, proteins and carbohydrates and have been implicated in more than 100 diseases (Tanizawa et al., 1992; Gulcin et al., 2003). Glutathione content decreased significantly in HCAs treated rat group suggesting its rapid oxidation. Glutathione has a beneficial effect by virtue possing-SH group so, helps to protect biological membranes, which are readily susceptible to peroxidation. GSH acts directly as an antioxidant and also participates in catalytic cycles of several antioxidant enzymes such as glutathione peroxidase and glutathione reductase. The reduction of GSH shows the failure of primary antioxidant system to act against free radicals (Aydogan et al., 2010).

The results in Fig (2) showed a significant decrease $(\mathrm{P} \leq 0.05)$ in Catalase (CAT) and GSHPx activities in HCAs group. Hence, this enzyme protects tissues from highly reactive hydroxyl radical $(\bullet \mathrm{OH})$, derived from $\mathrm{H}_{2} \mathrm{O}_{2}$ (Huang et al., 2004). Catalase and GSHPx catalyze dismutation of the superoxide anion $\left(\mathrm{O}_{2}-\right)$ into hydrogen peroxide $\left(\mathrm{H}_{2} \mathrm{O}_{2}\right)$ which then convert hydrogen peroxide to water, in this manner, providing protection against reactive oxygen species (ROS) (Sayed-Ahmed et al.,2010). Thus, the decrease in CAT activity increased the toxic effect of the free radicals formed from the HCAs effect.

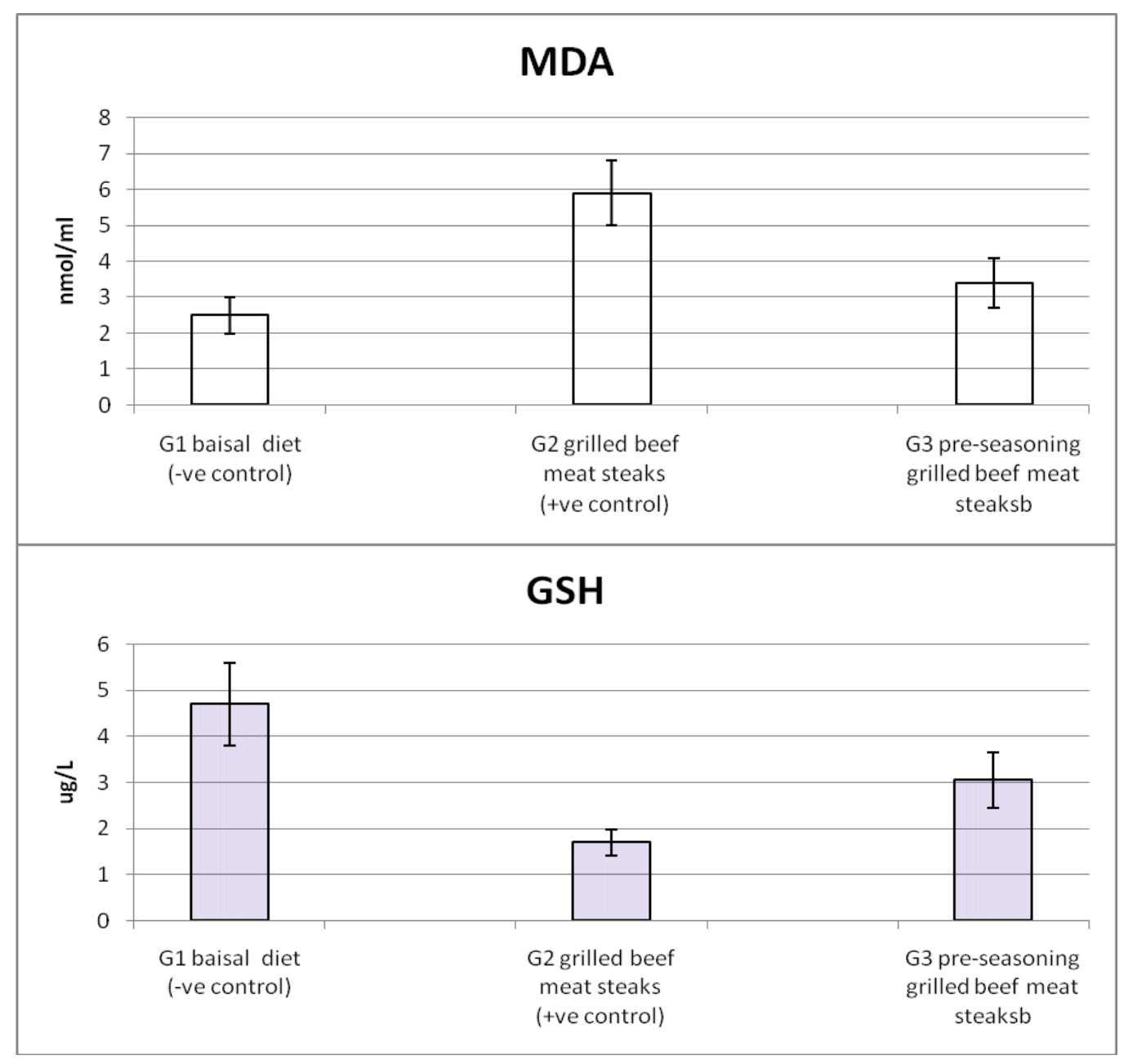

Fig.1: Effect of experimental diets on oxidation state of rats. (MDA: Lipid peroxide (malonaldhyde) GSH : Reduced glutathione content.) 


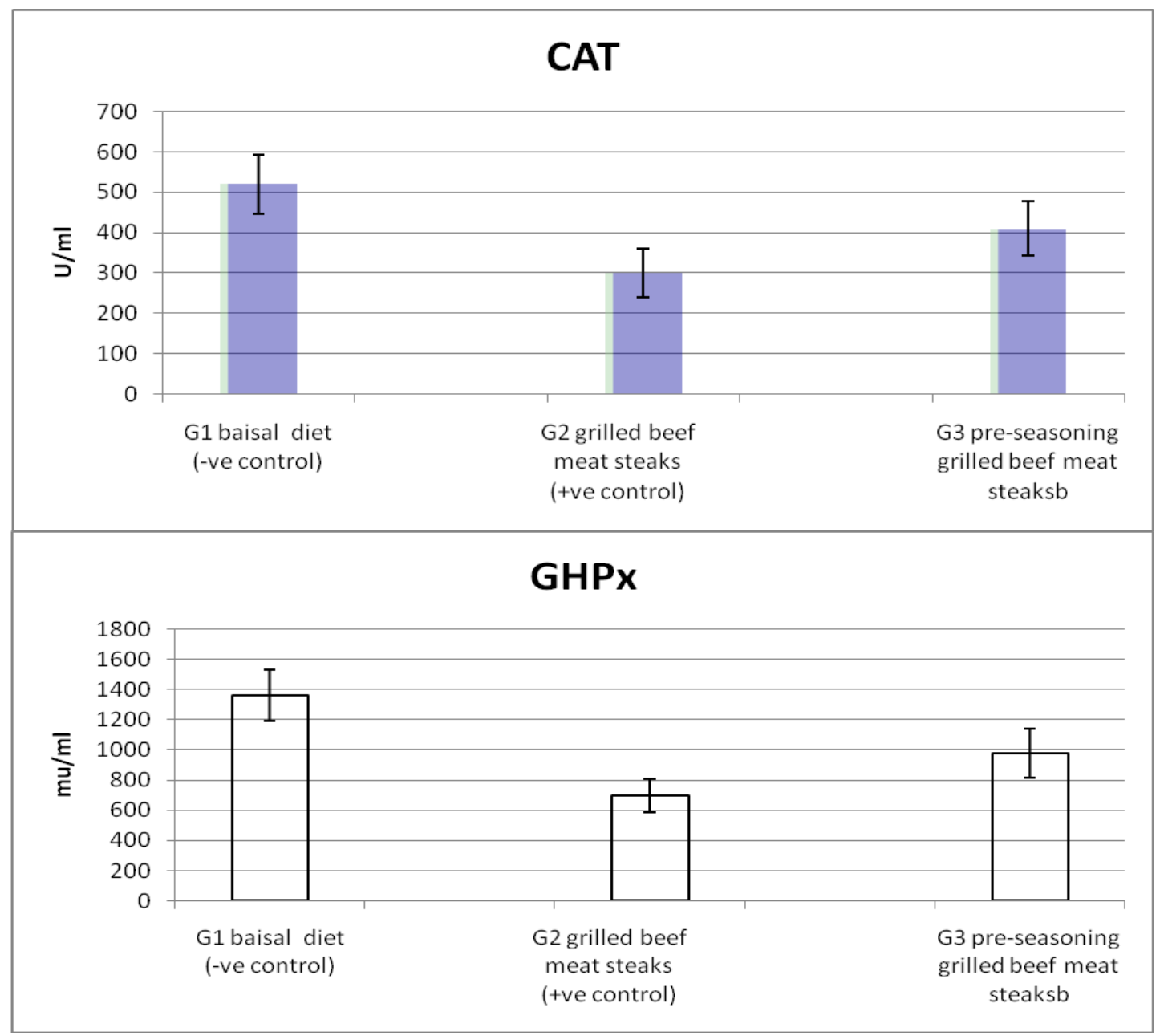

Fig.2: Effect of experimental diets on oxidation enzymes of rats. (CAT: Catalase GHPx: Glutathione peroxidase.)

Antioxidants reduce the cellular damage resulting from interaction between lipid, protein and DNA molecules and ROS. Therefore, rats fed on seasoning beef meat steaks with $0.5 \%$ clove powder before grilling significantly improved all above tested parameters $(\mathrm{P} \leq 0.05)$ compared with positive control (un-seasoning beef steaks) as illustrated in Figs (1\&2). The results indicated that antioxidant species showed protective effect against tested HCAs induced toxicity by modulating lipid peroxidation and increased antioxidant defense system. Our results were agreed with previous studies. Sadeek and Abd El-Razek (2010) found that supplementation with either $2 \%$ turmeric , clove, chili, or cardamom significantly decreased $(\mathrm{p}<0.05)$ serum MDA and liver iron deposition compared to iron overloaded group with the lowest value in group fed $2 \%$ clove . On the other hand, a significant increase ( $p<$ 0.05 ) in serum catalase in groups supplemented with different spices was reported with the highest value in group fed 2\% clove . Also, Abozid and El-Sayed (2013) reported that clove extract and clove essential oil resulted significant reduction of lipid peroxidation product induced by $\mathrm{H}_{2} \mathrm{O}_{2}$.

Possible mechanism behind this is the antioxidant spices like clove scavenges or neutralizers the free radicals interacts with oxidative cascade quenches oxygen, inhibits oxidative enzymes like cyochrome (c) 2011-15, JDDT. All Rights Reserved
P450 and chelates metal ions like $\mathrm{Fe}^{+2}$, inhibits peroxidation of membrane lipids and maintains cell membrane integrity and their function in the liver, lung and kidney. In fact, antioxidants can act as inhibitors along the different pathways of reaction, preventing the mutagens formation through radical quenchers and free radical scavengers activity or preventing the biotransformation of premutagens into reactive metabolites by inhibiting metabolic activation, or direct noncovalent interactions of antioxidants with HCAs, which may lead to the sequestration of mutagens, blocking their bioavailability and thus reducing their genotoxic potential. (Dashwood et al., 2002; Osowski et al., 2010). It has been reported that the antioxidant activity of clove could be attributed to its phytochemical contents which increases the amount or increase the activity of antioxidant enzymes (Rock et al ., 1996), or due to their trace element contents which are required for the antioxidant enzyme activity (Lamp (1999; Sharma et al . 2001). Clove essential oil showed the highest antioxidant activity compared with 16 essential oils tested by ferric reducing power assay (Teixeira et al., 2013). Clove essential oil has been reported in previous studies as one of the strongest antioxidants, even higher than some synthetic antioxidants like BHT or butylated hydroxyanisole (Misharina and Samusenko, 2008; Jirovetz et al., 2006; 
Wei et al., 2010). The strong activity of clove essential oil can be due to the presence of eugenol, the main constituent of this essential oil, which is known to have antioxidant activity (Ruberto and Baratta, 2000; Wei et al., 2010). The antioxidant activity of eugenol was evaluated by the extent of protection offered against free radical-mediated lipid peroxidation using both in vitro and in vivo studies. Eugenol completely inhibited both iron and Fenton reagent-mediated lipid

\section{REFERENCES}

1. A.O.A.C. (2005). Association of Official Analytic Chemist, "Official Method of Analytic Chemist," 18th Edition, AOAC, Washington.

2. Abozid, M.M and EL-Sayed S. M. (2013). Antioxidant and Protective Effect of Clove Extracts And Clove Essential Oil On Hydrogen Peroxide Treated Rats. International Journal of ChemTech Research,5(4) 1477- 1485.

3. Aebi, H., (1984). Catalase in vitro, isolation, purification, characterization, and assay of antioxygenic enzymes. Methods Enzymol., 105: 121-126.

4. Alaejos, M. S. and Afonso, Ana M. (2011). Factors That Affect the Content of Heterocyclic Aromatic Amines in Foods.Comprehensive Reviews in Food Science and Food Safety. Vol.10, 52-108.

5. Aydogan. M, Korkmaz. A, Barlas. N and Kolankaya. D, (2010). "Pro- " oxidant effect of vitamin C coadministration with bisphenol A, nonylphenol, and octylphenol on the reproductive tract of male rats," Drug and Chemical Toxicology, vol. 33, no. 2, pp. 193-203.

6. Balogh, Z., Gray, J. I., Gomaa, E. A. and Booren, A. M. (2000). Formation and inhibition of heterocyclic aromatic amines in fried ground beef patties. Food and Chemical Toxicology, 38(5), 395-401.

7. Bindhumol, V., K. C. Chitra, and P. P. Mathur, (2003). "Bisphenol A induces reactive oxygen species generation in the liver of male rats," Toxicology, vol. 188, no. 2-3, pp. $117-$ 124.

8. Dashwood RH. (2002). Modulation of heterocyclic amineinduced mutagenicity and carcinogenicity: an 'A-to-Z' guide to chemopreventive agents, promoters, and transgenic models. Mutat. Res.- Rev. Mut. Res. 511(2):89-112.

9. Diego Francisco Cortés-Rojas, Claudia Regina Fernandes de Souza; Wanderley Pereira Oliveira (2014). Clove (Syzygium aromaticum): a precious spice/Asian Pac J Trop Biomed 2014; 4(2): 90-96.

10. Farag, Manar, M.A. (2014). Effect of seasoning on formed imidazoquionline compound concentrate during beef meat cooking methods at high temperatures Journal of American Science 2014;10(12) 131- 137

11. Fossati, P., L. Prencipe, (1982). Serum triglycerides determined calorimetrically with an enzyme the produces hydrogen peroxide, clin. Chem., 28: 2077-08.

12. Gibis, M. (2007). Effect of oil marinades with garlic, onion, and lemon juice on the formation of heterocyclic aromatic amines in fried beef patties. J Agric Food Chem55(25):10240-7.

13. Gibis, Monika and Weiss, Jochen (2010).Inhibitory effect of marinades with hibiscus extract on formation of heterocyclic aromatic amines and sensory quality of fried beef patties. Meat Science 85, 735-742.

14. Gibis, Monika and Weiss, Jochen (2012). Antioxidant capacity and inhibitory effect of grape seed and rosemary extract in marinades on the formation of heterocyclic amines in fried beef patties. Food Chemistry 134, 766-774/

15. Gülçin İ (2011). Antioxidant activity of eugenol: a structureactivity relationship study. J Med Food 14(9): 975-985.

16. Gulcin,I., Buyukokuroglu, M.E., Kufrevioglu,O.I., (2003). Metal chelating and hydrogen peroxide scavenging effects of melatonin. J. Pineal Res. 34, 278-281.

17. Gülçina İ, Şatb İG, Beydemira Ş, Elmastaşc M, Küfrevioglu Öİ (2004). Comparison of antioxidant activity of clove peroxidation. The inhibitory activity of eugenol was about five fold higher than that observed for $\alpha$ tocopherol (Nagababu et al., 2010).

In conclusion: our result suggested that seasoning of beef meat with antioxidant species clove powder before grilling is a very simple but efficient method to reduce exposure to HCAs and their potential hazards to human health.
(Eugenia caryophylata Thunb) buds and lavender (Lavandula stoechas L.). Food Chem 8(3): 393-400.

18. Halliwell,G. "Catalytic decomposition of cellulose under biological conditions," The Biochemical Journal, vol. 95, pp.35-40, 1965 .

19. Huang,J. P. H. Tan, B. K. Tan, and B. H. Bay, (2004). "GSTpi expression correlates with oxidative stress and apoptosis in breast cancer," Oncology Reports, vol. 12, no. 4, pp. 921925.

20. Jagerstad M, Laser Reutersward A, Olsson R, Grivas S, Nyhammar T (1983) Creatin(ine) andMaillard reaction products as precursors of mutagenic compounds: Effects of various amino acids. Food Chem 12: 255-264.

21. Jägerstad, M.; Skog, K.; Arvidsson, O.; Solyakov, A. Chemistry, formation and occurrence of genotoxic heterocyclic amines identified in model systems and cooked foods. Z. lebensm- Unters. -Forsch. (1998), 207, 419-427.

22. Jirovetz L, Buchbauer G, Stoilova I, Stoyanova A, Krastanov A, Schmidt E. (2006). Chemical composition and antioxidant properties of clove leaf essential oil. J Agric Food Chem. 54(17): 6303-6307.

23. Kaban, Oz F. G. and Kaya M. (2007). Effects of cooking methods on the formation of heterocyclic aromatic amines of two different species trout. Food Chem104(1):67-72.

24. Kikugawa K. (1999). Involvement of free radicals in the formation of heterocyclic amines and prevention by antioxidants. Cancer Lett. 143(2):123-6.

25. Kikugawa, K. (2004) Prevention of mutagen formation in heated meats and model systems. Mutat. Res, 19, 431-439.

26. Knize M. G., Sinha R., Rothman N., Brown E. D., Salmon C. P., Levander O. A., Cunningham P. L. and Felton J. S. (1995). Heterocyclic amine content in fast-food meat products. Food and Chemical Toxicology 33, 545-551.

27. Lampe, J.W. (1999). Health effects of vegetables and fruit : assessing mechanisms of action in human experimental studies. Amer.J.Clin.Nutr.,70(3):475S-490S .

28. Lauber SN, Gooderham NJ. (2011). The cooked meat-derived mammary carcinogen 2-amino-1-methyl-6phenylimidazo[4,5-b]pyridine promotes invasive behavior of breast cancer cells. Toxicology 279(1-3):139-45.

29. Messner, C., \& Murkovic, M. (2004). Evaluation of a new model system for studying the formation of heterocyclic amines. Journal of Chromatography B, 802(1), 19-26.

30. Misharina, T., Samusenko, A. (2008). Antioxidant properties of essential oils from lemon, grapefruit, coriander,clove, and their mixtures. Appl. Biochem. Microbiol. 44, 438-442.

31. Murkovic M, Steinberger D, Pfannhauser W. (1998). Antioxidant spices reduce the formation of heterocyclic amines in fried meat. Z Lebensm. Unters. Forsch. A-Food Res. Technol.207(6):477-80.

32. Murkovic M. (2007). Analysis of heterocyclic aromatic amines. Anal.Bioanal.Chem. 389(1):139-146.

33. Nagababu,E., Rifkind,J.M., Boindala ,S.; Nakka,L. (2010). Assessment of Antioxidant Activity of Eugenol In Vitro and In Vivo.Free Radicals and Antioxidant Protocols . Methods in Molecular Biology .volume 610 .part 2 (165-180)

34. Nagao, M., Honda, M., Seino, Y., Yahagi, T., \& Sugimura, T. (1977). Mutagenicities of smoke condensates and the charred surface of fish and meat. Cancer Letters,2(4-5), 221-226. 
35. Nagao, M.; Sugimura, T. Food borne carcinogens : heterocyclic amines. Wiley: Chichester; NewYork, 2000; p.373.

36. Nandi,D. R. C. Patra, and D. Swarup (2005). "Effect of cysteine, methionine, ascorbic acid and thiamine on arsenicinduced oxidative stress and biochemical alterations in rats," Toxicology, vol. 211, no. 1-2, pp. 26-35.

37. NTP, U.S. Department of Health and Human Services, Public Health Service. (2011). Report on Carcinogens. 12

38. Osowski, A., M. Pietrzak, Z. Wieczorek, and J. Wieczorek, (2010). "Natural compounds in the human diet and their ability to bind mutagens prevents DNA-mutagen intercalation," Journal of Toxicology and Environmental Health A, vol. 73, no. 17-18, pp. 1141-1149.

39. Paglia, D.E., W.N. Valentine, (1967). J.Lab.Clin. Med., 70: 158-169

40. Pérez-Jiménez J, Neveu V, Vos F, Scalbert A. Identification of the 100 richest dietary sources of polyphenols: an application of the phenol-explorer database. Eur J Clin Nutr 2010; 64(Suppl 3): S112-S120.

41. Philippe A. Guy, Eric Gremaud, JaniqueRichoz, Robert J. and Turesky, (2000).Quantitative analysis of mutagenic heterocyclic aromatic amines in cooked meat using liquid chromatography-atmospheric pressure chemical ionisation tandem mass spectrometry. Journal of Chromatography A, 883, 89-102

42. Quelhas, C. Petisca a, O. Viegasa,b, A. Melo a, O. Pinhoa,b, I.M.P.L.V.O. Ferreira, (2010).Effect of green tea marinades on the formation of heterocyclic aromatic amines and sensory quality of pan-fried beef. Food Chemistry 122, 98-104.

43. Robert J. Turesky,' W. G. Sara StillweII, Paul L. Skipper, and Steven R. Tannenbaum (1993). Metabolism of the Foodborne Carcinogens 2-Amino-3-methylimidazo- [4,5fjquinoline and 2-Amino-3,8- dimethyl midazo[4,5-quinoxaline. Pharm. Bull. 40, 1940-1942.

44. Rock,C.L.; Jacob,R.A. and Bowen ,P.E.(1996): Update on the biological characteristics of the antioxidant micronutrients Vitamin C, vitamin E, and the carotenoids .J.Am.Diet Assoc.96:693-702.

45. Ruberto, G., Baratta, M.T. (2000). Antioxidant activity of selected essential oil components in two lipid model systems. Food Chem. 69: 167-174.

46. Sadeek, Eman A. and Fatma H. Abd El-Razek (2010). The Chemo-Protective Effect of Turmeric, Chili, Cloves and Cardamom on Correcting Iron Overload-Induced Liver Injury, Oxidative Stress and Serum Lipid Profile in Rat Models. Journal of American Science, 6(10), 7 02- 712

47. Satoh, K., (1979). "Serum lipid peroxide in cerbrovascular disorders determinated by a new colorimetric method". Clin. Chem. Acta., 20: 37-43.

48. SAS/STAS, "User's Guide, Statistical analysis system institute, Cary, NC," 1990. Satoh, K., 1979. "Serum lipid peroxide in cerbrovascular disorders determinated by a new colorimetric method". Clin. Chem. Acta., 20: 37-43.

49. Sayed-Ahmed, M. M. A. M. Aleisa, S. S. Al-Rejaie , (2010). "Thymoquinone attenuates diethylnitrosamine induction of hepatic carcinogenesis through antioxidant signaling," Oxidative Medicine and Cellular Longevity, vol. 3, no. 4, pp. 254-261.
50. Shan B, Cai YZ, Sun M, Corke H (2005). Antioxidant capacity of 26 spice extracts and characterization of their phenolic constituents. J Agric Food Chem; 53(20): 77497759.

51. Sharma, R.A.; Verschoyle, C.R.; Hill, K. ; Williams, K. LeRurattim, C. ;.Manson, L .Marnet, W. Steward and Gescher.(2001): Effect of dietary curcumin on glutathione Stransferase and malondialdehyde- DNA adducts in rat liver and colon mucosa .relationship with drug levels . Clin.Cancer Res.71452-8.

52. Smith JS, Amerı F, Gadgil P (2008) Effect of marinades on the formation of heterocyclic amines in grilled beef steaks. Journal of Food Science 73: 100-105.

53. Stavric B (1994) Biological significance of trace levels of mutagenic heterocyclic aromatic amines in human diet: A critical review. Food Chem Toxicol 32: 977-994.

54. Sugimura T (2002). Food and cancer. Toxicology. 182: 1721.

55. Sugimura, T., Wakabayashi, K., Nakagama, H., \& Nagao, M. (2004). Heterocyclic amines: mutagens/carcinogens produced during cooking of meat and fish. Cancer Science, 95(4), 290299.

56. Tang D, Liu JJ, Rundle A, Neslund-Dudas C, Savera AT, Bock CH, Nock NL, Yang JJ, RybickiBA. (2007). Grilled meat consumption and PhIP-DNA adducts in prostate carcinogenesis. Cancer Epidemiol. Biomarkers Prev. 16(4):803-8.

57. Tanizawa, H., Ohkawa, Y., Takino, Y., Ueno, A., Kageyama, T.,Hara, S., (1992). Studies on natural antioxidants in citrus species. I.Determination of antioxidant activities of citrus fruits. Chem.

58. Teixeira, B., Marques, A., Ramos, C., Neng, N. R., Nogueira, M.F., Saraiva, J. A., and Nunes, M. L. (2013). Chemical composition and antibacterial and antioxidant properties of commercial essential oils. Industrial Crops and Products 43 : 587-595..

59. Tsen SY, Ameri F, Smith JS. (2006). Effects of rosemary extracts on the reduction of heterocyclicamines in beef patties. J. Food Sci. 71(8):C469-73.

60. Verdin, S.H. (2002). Prevention of Heterocyclic amines in beef fortified with spices. Masters Thesis, Kansas State University, Manhattan, KS.

61. Wei, A., Shibamoto, T. (2010). Antioxidant lipoxygenase inhibitory activities and chemical compositions of selected essential oils. J. Agric. Food Chem. 58: 7218-7225.

62. Weisburger JH, Veliath E, Larios E, Pittman B, Zang E, Hara Y. (2002). Tea polyphenols inhibit the formation of mutagens during the cooking of meat. Mutat. Res.-Genet. Toxicol. Environ. Mutag. 516(1-2):19-22.

63. Zochling, S.,\&Murkovic, M.(2002). Formation of the heterocyclic aromaticaminePhIP: identification of precursors and intermediates. Food Chemistry, 79(1), 125-134.

64. Zsivkovits,M., Kassie Fekadu, Gerhard Sontag,Ursula Nabinger, Wolfgang W.Huber, Michael Kundi, Asima Chakraborty, Helmuth Foissy and Siegfried Knasmuller (2003). Prevention of heterocyclic amine-induced DNA damage in colon and liver of rats by different lactobacillus strains. Carcinogenesis vol.24 no. 12 pp.1913-1918 